Western University Scholarship@Western

Department of Economics Research Reports

Economics Working Papers Archive

1999

\title{
Slobodan Milosevic and the Fire of Nationalism
}

Ronald Wintrobe

Follow this and additional works at: https://ir.lib.uwo.ca/economicsresrpt

Part of the Economics Commons

Citation of this paper:

Wintrobe, Ronald. "Slobodan Milosevic and the Fire of Nationalism." Department of Economics Research Reports, 9917. London, ON: Department of Economics, University of Western Ontario (1999). 
ISSN:0318-725X

ISBN:0-7714-2224-5

\title{
53957001
}

\section{RESEARCH REPORT 9917 \\ Slobodan Milosevic and the Fire of Nationalism \\ ECONOMICS REFERENCE CENTRE \\ by \\ MAR - 82000 \\ Ronald Wintrobe \\ UNPVERSITY OF WESTERN ONTARTO}

November 1999

\author{
Department of Economics \\ Social Science Centre \\ University of Western Ontario \\ London, Ontario, Canada \\ N6A 5C2 \\ econref@julian.uwo.ca
}




\title{
SLOBODAN MILOSEVIC AND THE FIRE OF NATIONALISM ${ }^{1}$
}

\author{
by \\ Ronald Wintrobe \\ Department of Economics \\ University of Western Ontario \\ London, Ontario N6A 5C2
}

November 23, 1999

'Previous versions of this paper were given at the University of Montreal and as an Invited Lecture at the Institute of Macroeconomic Analysis and Development's conference "Institutions in Transition", Maribor, Slovenia, October 8-9,1999. I am grateful to Leonard Dudley, Gianluigi Galeotti, Mario Ferrero, Katell Legouvren, Adi Schnytzer, Janez Sustersic, Bob Young and to the participants in those seminars for helpful comments. Any errors are my own. 


\section{ABSTRACT \\ SLOBODAN MILOSEVIC AND THE FIRE OF NATIONALISM}

This paper is an attempt to understand the Milosevic regime in Serbia. I focus on nationalism, ethnic cleansing and war, especially on the most recent war with NATO. I first look at how its behaviour has typically been understood in the popular press and in the light of the most prominent social science theories. I then suggest a different approach based on my model of dictatorship. The basic argument is simple: First, like any dictator, Milosevic needs support in order to survive in office. His provocative and warlike actions towards other groups are best understood, not as the latest round in a centuries-old tradition of ethnic fighting, but as the attempts of a competitive politician trying to survive in a situation where the old bases

of power have collapsed. Second, in attempting to survive the wave of democratization that swept Eastern Europe after 1989, Milosevic played a wild card - the nationalist card. Nationalism can be wild because, under some circumstances, it is contagious. Especially when combined with the security dilemma, it can spread uncontrollably. Ethnic cleansing and war are seen in this light as neither deliberate, coldly planned strategies of brutal repression, nor the resuits of complete miscalculation, but the results of a process in which the leadership of the regime was reacting to events which it may have set in motion, but did not entirely control. 


\section{INTRODUCTION}

Although the Cold War with Communism has disappeared, the foreign policy problems of the United States and the United Nations continue. If there is some general pattern or logic to them, it does not seem to be the "clash of civilizations" predicted by Huntington (1996) nor the universal convergence to capitalism and democracy predicted by Francis Fukuyama (1992). Instead, the central policy dilemma for the world community appears to be the persistence of dictatorships, or at least of highly imperfect or "ugly" democracies $^{2}$ and the problems caused by the interaction and conflict between these regimes and the democracies. The most obvious examples are the conflicts in Yugoslavia, the continuing conflict with Saddam Hussein, and the dilemma of how to deal with China. Some other problems, such as those in the Middle East, can be interpreted as largely caused by the persistence of dictatorship in much of that region. Of course, many other conflicts, for example those caused by terrorism, are related to the existence of other dictatorships such as Libya. And there is also of course the never-ending standoff between Fidel Castro of Cuba and the United States. These frictions and antagonisms continue to cause problems for a world community otherwise increasingly devoted to peace and human rights.

Why do dictatorships cause so many problems? The reason, I suggest, is not just that they are essentially aggressive or war-like, though this characterization is not an unfair description of the behavior of many undemocratic regimes. Insofar as they result in overt war, I will contend, the basic problem is the misunderstanding of their nature, that is of how these regimes work, by the theorists, politicians and citizens of democratic countries. To illustrate, consider Milosevic. Milosevic is often described as a dictator but he has won elections. The elections hardly measured up to the democratic ideal but there is little doubt that Milosevic faced real opposition in them. The precise nature of the post-Communist Serbian regime eludes scrutiny. As Robert Thomas puts it

\footnotetext{
${ }^{2} \mathrm{I}$ am indebted to Mario Ferrero and Vani Borooah for this phrase.
} 
...Serbia exists in a classificatory limbo where stunted democratic institutions mix uneasily with authoritarian structures and both of these elements are overshadowed by the sultanist influence of the leader of the ruling party, Slobodan Milosevic" (Thomas, 1999, pp. 3-4).

What is Milosevic? Is he "radical evil" incarnate as Susan Sontag (1999) has suggested, or just another Balkan strongman (Aleksa Djilas, 19993) trying to survive? Michael Ignatieff (1999, p. 75) suggests that he has "developed a new style of post-Cold War authoritarian populism" just as he had "pioneered ethnic cleansing and the use of refugees as a weapon of war..." ( p. 74). Of course, as of this writing (September 1999), Milosevic has, yet again, lost the war, this time with NATO. And perhaps the most appropriate label given to him nowadays is the one popularly given and officially sanctioned by Louise Arbour in her capacity as the Chief Prosecutor for the UN tribunal in the Hague: "War criminal". Yet Milosevic remains in power.

This paper is an attempt to understand the Milosevic regime. In particular, I focus on nationalism, ethnic cleansing and war, especially on the most recent war with NATO. I begin by looking at how he has typically been understood both in the popular press and in the light of the most prominent social science theories. I then suggest a different approach based on my $(1990,1998)$ model of dictatorship. The basic argument is simple: First, like any dictator, Milosevic needs support in order to survive in office. His provocative and warlike actions towards other groups like the Croatians and the Albanians are best understood, not as the latest round in a centuries-old tradition of ethnic fighting, but as the attempts of a competitive politician trying to survive in a situation where the old basis of power-the Communist system, Titoist version - has disintegrated. Second, in attempting to survive the wave of democratization that swept Eastern Europe after 1989, Milosevic played a wild card - the nationalist card. Nationalism can be wild because, under some circumstances, it is contagious. To revert to the metaphor that is central to this paper, once the fire of ethnic nationalism has been lit, especially when combined with the security dilemma, it can

${ }^{3}$ As quoted in the International Herald Tribune, May 1999. 
spread uncontrollably and do great damage. So I suggest that, in the end, Milosevic can be viewed as a typical totalitarian dictator confronted with the collapse of the basis of his support, who responded to this collapse by playing with the fire of ethnic nationalism. Ethnic cleansing and war are seen in this light as neither deliberate, coldly planned strategies of brutal repression, nor the results of complete miscalculation, but the results of a process in which the leadership of the regime was reacting to events which it may have set in motion, but did not entirely control.

The outline of the paper is as follows: The next section reviews a number of different points of view that have been put forward to explain the recent conflicts in the Balkans. Section 3 outlines the approach taken here and applies it to the Milosevic regime. Section 4 extends that approach to understand the contagion property of ethnic nationalism. Section 5 considers the origins and the conduct of the war between NATO and Serbia in this light and in the light of the standard rationalist approach to war. Section 6 concludes the paper.

\section{EXPLANATIONS OF MILOSEVIC'S STRATEGY}

Popular explanations of the conflicts between the Serbs and the Croatians or the Albanians tend to take one of two forms. Either the conflicts are attributed to: (i) Serbian aggression, or (ii) ancient hatreds. The appeal of the first explanation - Serbian aggression - is easy to understand. Under Slobodan Milosevic Serbia has fought four wars since 1989. The aim was obvious - the creation of greater Serbia. So the horrors associated with these conflicts could be blamed on one nation and even one man. In this vein, Susan Sontag (1999) justified NATO's attack on Serbia by referring to the presence of "radical evil" being loosed upon the world. Perhaps a more general pattern had emerged in the post-Cold War period, as Woodward (1995) suggested American policymakers thought, of "rogue or renegade states" headed by "“new Hitlers' such as Saddam Hussein in Iraq and Slobodan Milosevic, who defied all norms of civilized behavior and had to be punished to protect those norms and to protect innocent people" (Woodward, 1995, p. 7). 
One difficulty with this view is that, by all accounts, Milosevic appears to be no ideologue, but a simple opportunist. ${ }^{4}$ But if Milosevic is simply an opportunist, what opportunities or forces is he responding to in these acts of repression? What are the conditions that make such leaders possible? Perhaps, then, the Serbian people are to blame. But what makes them different from other peoples? Indeed, on this point, Milovan Djilas, in an interview with Michael Ignatieff, suggests that "the West's greatest mistake...is that it has 'satanized' the Serbs" (Ignatieff (1994), p. 38).

The second line of thought is that the Yugoslav and Bosnian conflicts were based on the revival of ancient hatreds or ethnic conflicts after the fall of Communism. On this view, Tito provided the strong leadership, backed by the repressive powers of the Communist system to contain the ancient hatreds, which nevertheless continued to simmer under the surface of Communism and self-management. When Communism disintegrated, they just floated back up to the top. However, as recently as 1990 , journalists travelling in the region reported that most people seemed to have had no use for the polarizing rhetoric of the minority of extremists. Croats and Serbs lived together in relative contentment according to Glenny (1992), and many others. Gagnon (1994/5) points out that Yugoslavia never saw the kind of religious wars seen in Western and Central Europe; that Serbs and Croats never fought before this century; that intermarriage rates were quite high in those ethnically-mixed regions that saw the worst violence; and that sociological polling as late as $1989-90$ showed a high level of tolerance especially in the mixed region (p. 133-34).

In one way, then, the central problem with which this paper is concerned is the sudden emergence of nationalism or the salience of ethnic differences. As Xavier Bougarel has put it "How is it that a people who voted in one year $74 \%$ in favor of banning certain kinds of groups voted the second year for those

${ }^{4}$ See, for example, Aleksa Djilas' “A Profile of Slobodan Milosevic" (1993), who describes Milosevic as "essentially an ideological eclectic and a political opportunist" (p. 94). Ignatieff (1994) suggests that "few people I meet in Belgrade believe Milosevic himself has any deep nationalist convictions. He merely knows that when he shouts from the podium 'nobody will ever beat the Serbs again!' they applaud him to the rafters" (1994, pp. 37-38). 
groups in exactly the same proportion?"' The most commonly accepted answer to this question in social science appears to be the concept of the security dilemma. The problem highlighted in the security dilemma is that a nation's attempt to provide itself with security may be interpreted by another nation as aggressive or threatening, causing that nation to arm in response. A spiral can be set in motion, such as the well-known nuclear arms race, in which each nation's attempt to provide itself with nuclear weapons for defensive purposes causes other nations to arm in return, causing the first nation to feel more insecure, and so on. Posen (1993) was the first to apply the logic of the security dilemma to ethnic conflict. After the collapse of the Soviet system, the different ethnic groups in Yugoslavia were essentially in a situation of "emerging anarchy"analogous to that of the international system which is the normal subject of the security dilemma. Under these conditions each ethnic group naturally sought to protect itself from aggression by other groups, but these actions were interpreted as aggressive by others, and so on.

Woodward (1997) applies the security dilemma argument to Yugoslavia after the collapse of Communism even more broadly than Posen did:

"If Yugoslavs are classified as members of ethno-national groupings, everyone belonged to a numerical minority. The fears engendered by the situation under anarchy are enhanced by the fact of frequent local (territorially concentrated) majorities............Groups perceived the resources of other groups as more threatening (more 'offensibly capable') than their own. Slovenes interpreted their own refusal to abide by federal rulings as a matter of rights and safeguarding the Constitution of 1974, whereas others who defended the common umbrella for security and transfers saw this act as a threat to their survival.......Slovenes were unaware of the power of their wealth over government policy, Croats of their fascist past, and Muslims and Albanians of the fears engendered by their birth rates and new national assertiveness." (1997, p. 8).

${ }^{5}$ Xavier Bougarel, "Bosnia and Herzegovina-State and Communitarianism" in David A. Dyker and Ivan Vejvoda, eds., Yugoslavia and After: A Study in Fragmentation, Despair and Rebirth London: Longmans, 1996., p. 253-4, quoted from Woodward (1997), p. 3. 
The difficulty with this line of thought is that, if taken literally, it would seem that ethnic conflicts would be exploding everywhere. Instead, as pointed out by Fearon and Laitin (1996) and by Figueiredo and Weingast (1998) inter-ethnic relations are normally peaceful. Overt ethnic conflict is rare, yet there are many, many situations where ethnic groups formally find themselves in the situation of the security dilemma. One reason for this may be, as Fearon (1998), points out, that it is never made clear why signalling between groups or states cannot be used to reduce the uncertainty about each other's intentions which is the real source of the security dilemma.

Fearon and Laitin (1996) suggest an alternative model of why ethnic conflict arose after the collapse of Communism in Yugoslavia: Each ethnic group was unable to credibly commit to not to harm the minority within its borders. As Kydd (1997) also emphasizes, it is not anarchy per se but the inability to make a credible commitment not to attack the other party that gives rise to the security dilemma. However, it remains to be explained why this particular commitment problem persisted and even gave rise to war in postCommunist Yugosiavia, and not elsewhere in Eastern Europe or in the rest of the world. Figueiredo and Weingast (1998) suggest another condition - "confirming" behavior by the other side - for the security dilemma to hold. Suspicions about the others' behavior require confirmation - some sort of threatening action by the other side, for a spiral to develop. For example, the Croatian leader Franco Tudjman's refusal to disavow the symbols of the wartime Ustase regime. This "confirmed" the aggressive nature of the regime towards the Serbs within its borders, and made Serbia under Milosevic view any actions by the Croatians with suspicion.

In brief, it seems that the security dilemma, like ancient hatreds or Serbian aggression, may be necessary but is insufficient to explain the eruption of nationalism and ethnic conflict in Yugoslavia after the collapse of communism. In the following I essentially argue that the missing link is provided by the explosive quality of nationalism under certain conditions, especially the environment of post-totalitarian politics. 


\section{THE DICTATOR'S DILEMMA AND THE SECURITY DILEMMA}

One aspect of Milosevic's regime which plays no role in the security dilemma analysis is that his regime is often likened to a dictatorship. Perhaps the security dilemma, whether applied to ethnic groups or nations, is altered if one or more of the actors are dictators? What difference does this make? In order to explore this question, we have to ask, first of all, what do we know about dictatorship?

Perhaps the most common notion in political science is the idea that dictators rule by repression alone, as argued by Friedrich and Brzezinski (1965) and many others. The Milosevic regime is certainly repressive, in its control of the secret police and of the major media outlets. But if the Serbs are just a repressed population, why do they fight so hard? And why did they vote for Milosevic, who by all accounts appears to be popular and indeed has won several (more or less free) elections.

The study of dictatorship in public choice is relatively new. It includes Tullock's (1987) early book Autocracy and Bernholz's recent (eg., 1997) concept of Ideocracy, in which the values embedded in totalitarian ideologies are interpreted as the very aim (maximand) of totalitarian regimes. Another notion is Mancur Olson's (1993) "stationary bandit". Here the dictator maximizes income. Does this idea illuminate the workings of the Milosevic regime? One problem is that the model implicitly assumes that the dictator is safely in office. It is this which allows him to safely set the level of taxes and public goods to maximize his own income. Yet much of Milosevic's career seems to have been spent fending off challenges to his rule. Moreover, if Milosevic simply maximized income, why did he seek to expel the ethnic Albanians from Kosovo, rather than keep them around and subject them to revenue-maximizing taxation? Finally, the result of Milosevic's rule is that he has largely destroyed the Yugoslav economy. So if Milosevic is simply a kleptocrat, he is a very bad one.

The starting point of my own approach to these issues(e.g., Wintrobe 1990, 1998) is that the dictator's basic problem is how to stay in power--what I called the Dictator's Dilemma. The problem facing any autocrat is that of knowing how much support he has among the general population, as well as among 
smaller groups with the power to depose him. It is true that the dictator has power over his subjects. But this very power over them breeds a reluctance among the citizenry to signal displeasure with the dictator's policies. This fear on their part in turn breeds fear on the part of the dictator, since, not knowing what the population thinks of his policies, he cannot in the first instance know how secure is his tenure in office. Of course, the population has good reason to fear him. But this very fear (as well as jealousy) will make many among them look for ways to get rid of him. So the dictator has every reason to suspect that there are plots against him.

From a theoretical point of view, the Dictator's Dilemma originates in the lack of a mechanism to enforce political exchange. It is advantageous for the dictator to "buy off" some of his constituents, especially those who may be too powerful to repress, and those whose demands are easily satisfied. So a simple trade of rents or policies for support would solve the dictator's dilemma, and also allow his subjects to rest easily. But there is no mechanism analogous to legal contractual enforcement which would enforce this trade. Another way to put it is that the dictator and his subjects have a mutual signalling problem. The problem arises in political life generally. In democracy, politicians make promises, hoping for support (votes) in exchange. But how is this exchange enforced? The problem is particularly severe in dictatorship, because the institutions of democracy such as elections, a free press and an independent judiciary all provide means whereby dissatisfaction with public policies may be communicated between citizens and their political leaders. In dispensing with these institutions, the dictator gains a freedom of action unknown in democracy, but at a cost: the loss of the capacity to find out just how popular (and therefore how safe) he really is.

The implication is that dictators do not rule by repression alone. They also seek ways to build support among the population. Dictatorships with any permanence are those that discover and institutionalize mechanisms that "automatically" both reward their supporters and monitor their support and that fund these programs through taxation and systematic repression of the opposition. These institutions of repression and redistribution partially solve the dilemma in one way or another and define the character of the dictatorship. 
Thus in my book (Wintrobe (1998)) I derived different types of regimes as special cases of the general model. One way to classify them is by the levels of repression and loyal support: I defined four types: tinpots, with low support and low levels of repression, tyrants, with high levels of repression and low loyalty, timocrats (low repression, high loyalty) and totalitarians (high levels of both repression and loyalty).

The basic notion, then, is very simple and can be summarized in two propositions: (1)Dictators have a problem staying in power, and many of their actions can be explained by the competitive struggle to survive in office. (2) They need to cultivate loyalty as well as to use repression in order to do so.

It is straightforward to produce evidence that this point of view illuminates the working of the Milosevic regime. In the late 1980 's the regime was faced with a fall in support, and that Milosevic, like any dictator, increased repression and tried to find ways to restore loyal support on the part of the population. The strategies perfected in his rise to power have been well documented ${ }^{6}$. As is well known, in the 1980's Milosevic was a communist apparatchik. In 1984 he became the head of the Belgrade Communists. He was a party conservative, opposed to the reform movements who were in favour of greater reliance on private enterprise, multiple candidate elections and so forth. Shortly after coming to power as head of the Belgrade party organization, Milosevic began a campaign stressing ideological orthodoxy and shifting attention to ethnic issues. He was part of a wide conservative coalition in the Serbian party leadership, which included local and regional party elites, orthodox Marxist intellectuals, nationalist writers and parts of the Yugoslav army (Gagnon (1994/5), op.cit. pp. 143, 145). In 1986 he was elected head of the Serbian party's central committee. According to Aleksa Djilas: "He [Milosevic] had been president of the Serbian party for only a little over a year when he began to fearlessly to attend mass rallies, give speeches and interviews, and generally excite powerful nationalist passions"(Djilas (1993), p. 83).

According to Robert Thomas (1999):

'The details of the competitive strategies used in Milosevic's rise to power can be found in any number of historical sources. Here, we rely especially on Dallago and Uvalic ((1998), Djilas (1993), Gagnon (1994 and 1994/5) Ramet (1996) and Thomas (1999)). 
"After the famous rally in 1987 at which Milosevic declared to the demonstrators 'no one should dare to beat you', a lengthy meeting followed ('The Night of Hard Words') in which Milosevic heard the manifold grievances of the protestors. From that moment he obeyed the nationalist imperative and made the cause of the Kosovo Serbs his own....On returning to Belgrade he encapsulated his new priorities when addressing a meeting of the Executive of the League of Communists: 'What we are discussing here can no longer be called politics, it is a question of the fatherland'. Milosevic sought to place himself at the head of a mass movement ('the happening of the people') whose aims were ostensibly nationalist, seeking to restore Serbian central control over the provinces, and direct it against the Party establishment ('the anti-bureaucratic revolution')" (Thomas, 1999, p. 44).

These meetings were followed by a series of mass demonstrations, organized by Milosevic and his supporters, known as "rallies for truth" (Thomas, 1999, p. 45). Between July 1998 and the Spring of 1999, 100 such meetings took place across Serbia involving an estimated cumulative total of five million people. The slogans on placards at meetings were frequently strident and nationalist in tone, such as "In all the places where there are Serbian souls, that is the home and the heart place of my birth" (Thomas,1999, p. 45). Milosevic's emphasis on "anti-bureaucratic" reform caught the mood of widespread public anger at the corruption and nepotism which pervaded the Party structures. According to Thomas, a climatic moment was the Vidovdan rally of 28 June 1989 of the Kosovo Polji and marking the $600^{\text {th }}$ anniversary of the Serbian defeat at the Battle of Kosovo. The rally symbolized the emerging rapprochement between the Milosevic regime and the Serbian orthodox church. As Milosevic addressed his audience (he spoke of the "heroes" of the battle of Kosovo) portraits of [the medieval Serbian leader] Lazar and Milosevic were held aloft by members of the audience, the medieval monarch alongside the Communist apparatchik. (Thomas (1999), pp. 50-51).

By 1990, however, Communism was disappearing everywhere in Eastern Europe, reformers were coming into power and the people were demanding freedom in all the former Communist states. In the Spring 
1990 elections in Slovenia and Croatia openly antisocialist parties took power in an apparent backlash against Milosevic. The Federal Prime Minister Markovic pushed bills through the federal assembly legalizing a multi-party system and in July 1990 formed a political party to support his reforms. And opposition forces within Serbia itself began organizing and pressuring the regime for multi-party elections, holding massive protest railies in May (Gagnon, 1994, p. 153). Milosevic's response to these challenges in the 1990s was essentially to increase the level of repression, including purges of the party, and to use ethnic nationalism and provocation as well as selective incentives (the distribution of rents) to try and restore the people's loyalty.

To begin with the use of selective incentives, in order to win the 1990 election, the Serbian government printed $\$ 2$ billion (U.S.) in overdue workers' salaries just before the December elections, the funds illegally taken from the federal treasury (Gagnon, 1994-95, p. 153). Bruno Dallago and Milica Uvalic detail the use of other selective incentives:

"For firms, the granting of preferential credits, import permits, or postponement of fiscal obligations, while for individuals, privileged access to scarce goods, nomination to high and influential positions in political structures, allocation of flats or houses in the best parts of Belgrade and Zagreb. ...Negative incentives included laying off non-national workers, open threat or drafting into the army of those individuals actively opposing the nationalist collective action in order to induce them to side with the privileged group" (Dallago and Uvalic, (1998) pp. 78-79).

Following the 1990 election, the strategy of provoking conflict along ethnic lines was stepped up. The immediate cause appeared to be the massive protest rallies held in Belgrade on March $9^{\text {th }}$ and $10^{\text {th }}$ in 1991. Prior to the elections, Milosevic's party, now renamed the Socialist Party of Serbia (SPS) having previously opened up the nationalist strategy, tried to appear moderate in order to portray the opposition Serbian Renewal Movement led by Vuk Draskovic as wanting to drag Serbia into war, and to paint itself as a moderating and progressive force (Gagnon, 1994-95, p. 155). Milosevic's immediate response to the rallies of March $9^{\text {th }}$ and $10^{\text {th }}$ was to call the army to put down the demonstrations. However, the military refused to use massive force. 
Shortly thereafter massive strikes aimed specifically against Milosevic's regime shook Serbia. Milosevic responded, according to Gagnon, by stepping up the strategy of provoking conflict along ethnic lines, labelling the protestors "enemies of Serbia" who were working with Albanians, Croats and Slovenes to try to destroy Serbia. The result was that

the Yugoslav army, despite its promises not to attack to Croatia, escalated the conflict in Croatia, and Serbian forces continued their strategy of provoking conflict in Slavonia and on the borders of Krajina, terrorizing civilian populations, destroying Croatian villages in Croat parts of town, bombing cities to drive out the population and forcing Serbs on threat of death to join them and point out Croat-owned houses. Serbs who openly disagreed with these policies were terrorized and silenced .... The human rights group Helsinki Watch noted that in the period through August 1991 (when the Croats finally went on the offensive and Croat extremists themselves undertook atrocities against civilians), by far the most egregious human rights abuses were committed by the Serbian guerillas and the Yugoslav army, including indiscriminate use of violence to achieve their goals of terrorizing the Serb population into submission and driving out the non-Serb population. This policy, by provoking extremists in Croatia into action, in effect became a self-fulfilling prophecy as the Serbian regime pointed to those atrocities as proof of its original charges (Gagnon (1994/5) p. 160)

At the same time, Serbia also stepped up the pressure on Bosnia. It now portrayed as the ethnic enemy the allegedly fundamentalist Muslim population of Bosnia, who were said to be seeking to impose an Islamic state and to perpetrate genocide against the Bosnian Serbs (Gagnon (1994/5) p. 161 ). These strategies would later be repeated vs the Albanians in Kosovo.

At the same time as these policies of nationalism and provocation to stimulate ethnic loyalty were pursued, Milosevic also pursued other policies which had the effect of increasing the level of repression. For example, he gained control of the secret police over the period 1987 to 1990 , and the police had, by the end of 1990 , according to Thomas (1999, p. 93) "begun to recruit individuals who would unofficially be willing 
to support the state, and Milosevic's agenda, through the use of extra political methods and physical force." Finally, the standard Communist weapon of securing authority - the purge - was used. According to Aleksa Djilas,

"At the beginning of 1988, just after Milosevic had consolidated his power, the Belgrade Youth Paper Mladost published a carefully compiled list of the 100 most prominent political figures in Serbia. By the beginning of 1993, only a handful of them remained in power. Milosevic had disposed of the others as they grew either too assertive or too compromised" (Djilas, 1993, p. 89).

The important lesson from our point of view of accounts like those of Djilas, Gagnon, or Thomas is that it seems clear that Milosevic was responding as a competitive politician, faced with a decline in support possibly large enough to keep him from remaining in office. He simply used nationalism and ethnic provocation (along with selective incentives and the purge) to restore the loyalty of the people and that of the bureaucratic functionaries to him so that he could remain in power at a time when communist regimes were collapsing everywhere else in Eastern Europe. His provocation of the Croations, Slovenians, the Albanians and so forth were driven largely not by ancient hatreds but by domestic politics. Thus, I agree with Gagnon's conclusion with respect to the true nature of the wars in Bosnia- Herzegovina, Croatia and Serbia that

"Far from addressing the root causes of the strife, the West has from the beginning allowed the image of 'ancient ethnic conflict' to blind it to the true nature of these wars: they are wars against democratization in Serbia, in Croatia and most tragically and horrifically in Bosnia" (Gagnon, 1994, p. 130).

However, no one suggests that Milosevic or the Serbian media were capable of reinvigorating Serbian nationalism in the absence of a receptive public. Thus, Snyder and Ballantyne quote the journalist Mark Thompson to the effect that "[The] Media did not inject their audiences with anti-Muslim prejudice or 
exploitable fear of Croatian nationalism. The prejudice and fear were widespread, latently, at least......" Aleksa Djilas puts it more colourfully:

The mass movement of Kosovo Serbs developed spontaneously....Milosevic only gradually overcame his caution and started supporting it, but he was nonetheless the first leading Communist to do so. With the help of the Party-controlled media and the Party machinery, he soon dominated the movement, discovering in the process that the best way to escape the wrath of the masses was to lead them. It was an act of political cannibalism. The opponent, Serbian nationalism, was devoured and its spirit permeated the eater. Milosevic reinvigorated the Party by forcing it to embrace nationalism (Djilas, 1993, p. 87).

Why were the nationalist strategies so successful? Why are the main opposition parties (e.g., Draskovic's SRM) in Serbia just as, if not more nationalistic as Milosevic's SPS? Are we back to "ancient hatreds" for an explanation? The next section offers an alternative point of view, by developing some of the properties of nationalism in more detail.

\section{UNDERSTANDING NATIONALISM}

Nationalism may be defined as a doctrine which "locates the source of individual identity within a 'people' or ethnic group who are "seen as the bearer of sovereignty, the central object of loyalty and the basis of collective solidarity" (Greenfield, 1992, p.3). Alternatively, according to Smith, nationalism is

..an ideological movement for the attainment and maintenance of autonomy, cohesion and individuality for a social group deemed by some of its members to constitute an actual or potential nation. In other words, nationalism is both an ideology and a movement, usually a minority one, which aspires to 'nationhood' for the chosen group; ..... 'nationhood' in turn comprises three basic

'Mark Thompson, Forging War, quoted in Jack Snyder and Karen Ballantine, "Nationalism and the Marketplace of Ideas", in Michael E. Brown, et. al., (1997). 
ideals, autonomy and self-government for the group, often but not always in a sovereign state, solidarity and fraternity of the group in a recognized territory or 'home', and third, a distinctive, and preferably unique, culture and history peculiar to the group in question.(Smith, p. 2)

Thus, the essence of ethnic nationalism is that it fuses citizenship with ethnicity and territory. All the conflicts arise when one of these three is problematical, for example, if an ethnic group does not possess a distinctive territory, or when there are other, minority, ethnicities located there, or if citizenship is granted on some other basis than ethnicity.

What is so important about ethnicity that singles it out as the criterion by which people select the group that is to govern itself? Why not use some other criterion? For example, one alternative criterion is civic nationalism. "Civic nationalism" may be defined as the doctrine which "maintains that the nation should be composed of all those -regardless of race, colour, creed, gender, language or ethnicity-who subscribe to the nation's political creed. This nationalism is called civic because it envisages the nation as a community of equal, rights-bearing citizens , united in patriotic attachment to a shared set of political practises and values." (Ignatieff (1994) pp. 3-4). For many, civic nationalism is an altogether more agreeable doctrine in that it is inclusive rather than exclusive.

But the exclusivity of ethnic nationalism is precisely what sometimes makes it so attractive from the point of view of a rational individual if not necessarily that of society. Elsewhere, I referred to this property of nationalism as "blocked entry and exit": To the extent that membership in the ethnic group is based on blood, outsiders are not allowed in, and insiders can never completely leave (Wintrobe 1995). In this way of thinking, the value of ethnic identification arises from the fact that it is a way of policing or preventing cheating ${ }^{8}$. Normally, unless the legal system works perfectly, there is always the possibility of being cheated

${ }^{8}$ Of course, from a rational choice point of view, one can also think of ethnic nationalism as providing utility directly, by analogy to a consumption good. People could get pleasure directly from the act of identifying with others in the same ethnic group as themselves. For many of the purposes of this paper, either this view or the investment point of view put forward in the text will suffice, as will be shown in the text where appropriate. 
in any exchange. Suppose that it is less likely that a person would cheat another person of the same ethnic group than someone unrelated by blood. Then ethnic networks (or ethnic capital) can compensate for the fact that the legal system does not work perfectly and help to underpin exchange. Indeed, if the ethnic group has a greater capacity to monitor or punish cheating this belief on the individual's part could be perfectly rational. ${ }^{9}$

On this view, ethnic networks can substitute for other forms of contractual enforcement such as legal contractual enforcement or hierarchical enforcement. Markets, authority, ethnicity and other institutions such as the family or the firm all provide alternative or substitute means of supporting exchange. So the failure of one of them will mean that people will tend to resort to one or more of the others. It follows that one reason that nationalism increased was that, with the failure of communism, and the fact that markets had not yet been established, ethnic networks provided the main alternative underpinning for people to cooperate and to engage in exchange.

Suppose, then, that the fall of communism combined with Milosevic's "anti-bureaucratic revolution" to result in an increase in cohesion within the Serbian ethnic group. On the investment view, it follows that the transactions costs for a Serb in dealing with other Serbs (the costs of trading with another member of the ethnic group) would be lower than before, essentially because the likelihood of being cheated is less. for either public or private transactions. On the consumption view, there is greater ethnic solidarity or identification. From either point of view, then, an increase in cohesion or ethnic solidarity therefore would raise individual utility. However, this is not the end of the story, as there may be other, external effects. Among the other effects which may be expected to occur are the following:

1. Increased cohesion tends to help solve the dictator's dilemma, if the dictator in office is or can become the leader of the ethnic group. That is, it raises the security, typically, of the leader in office.

\footnotetext{
${ }^{9}$ See Wintrobe (1995) or (1998) chapter 12 for details). For other rational choice approaches to ethnicity, see Bates (1983), the papers collected in Breton, Galeotti, Salmon and Wintrobe (1995), or Fearon and Laitin (1996) .
} 
The reason is simple: if the leader can succeed in getting people to define themselves in terms of their nation or ethnicity, he, as the leader of the nation or ethnic group, tends to become relatively more sure of their support. National or ethnic identities tend to divide the world into two groups, "us" and "them" and make it relatively hard to sit on the fence, i.e., they force people to choose. Thus the nationalist card is one way to solve the dictator's dilemma. To put it simply, at the extreme, if everyone who is a Serb supports the Serb leader, and everyone who is not Serb does not, then it is simple for the Serb leader to know who supports him and who does not.

2. Increased ethnic cohesion may give rise to the security dilemma. As initially argued by Posen (1993), group cohesion and a strong national identity are key ingredients of the combat power of armies. As he put it, "ever since the French revolution put the first politically motivated mass armies into the field, strong national identity has been understood by both scholars and practitioners to be a key ingredient of the combat power of armies....... [Therefore] Unless proven otherwise, one group is likely to assume that another group's sense of identity, and the cohesion it produces, is a danger. Because the cohesion of one's own group is an essential means of defence against the possible depredations of neighbours, efforts to reinforce cohesion are likely to be undertaken". (Posen, (1993), p.30)

In turn, some conditions which may make this dilemma particularly acute are: (1) the existence of "ethnic islands"-that is, situations where islands of one ethnic group's population are stranded in a sea of another. Under this scenario, it would be expected that only rapid offensive action would be able to save them should the other ethnic group decide to mistreat them; (2) when offensive weaponry is most feasible; (3) if there is a "window of opportunity" of greater superiority after collapse of an imperial empire, which opportunity is not expected to last. (4) the UN practise of imposing ceasefires, which legitimates victories in war and makes each side eager to acquire territory in advance of the imposed ceasefire. 
3. The increased cohesion tends to be infectious or to spread within the group. That is, nationalism is contagious: when some are nationalistic, it tends to make others of the same stripe more nationalistic.

To understand this last point, let us first note that there are two further properties of nationalism, which are of great importance, and which have not been called attention to previously in a precise way. They both follow from the fact that ethnic nationalism, whether looked at as social capital, or as identity, is intimately involved with tradition and with social interactions ${ }^{10}$. To see what this implies, let the individual's utility function be

$$
U(E(t), K(t), x(t))
$$

where $U$ is individual utility, $t$ indexes time, $E(t)$ is the individual's level of consumption or investment in ethnic capital today, $K$ is the stock of ethnic capital inherited from one's parents and one's own investments in the past, and $x$ refers to other goods or services that yield utility.

Now let us explore what happens when the stock of (ethnic) nationalistic sentiment $(K)$ increases. The first point is that nationalism tends to be enhanced by tradition or "habitual" in the sense that past consumption or investment enhances the the value of experience today:

$$
U_{E K}>0 \text {. }
$$

Equation (2) states that the larger is an individual's stock of ethnic capital $K$, the larger is the marginal utility (or marginal productivity, in the case of ethnicity as an investment) of ethnic consumption or investment today. To see this point, assume first that nationalism is a consumption good. For purposes of illustration only, let us look at a person who is of Italian descent but lives in Toronto, Canada, along with 400,000 or so others of Italian descent and two million or so non-Italians. Then to say that ethnicity is

${ }^{10}$ Breton and Wintrobe (1982) developed the concept of trust or networks as a substitute for lawbased exchange. Their concept of trust is the same as Coleman's concept of social capital. Katz and Shapiro (1985) originated the notion of "network externalities". The dynamic properties of social capital were developed in Becker (1996), chapter 1. 
traditional implies that, for this person, the greater his stock of knowledge of Italian culture, the greater his pleasure in going to some Italian cultural or political event, or reading Italian literature, today. This proposition seems reasonable. It suggests that ethnic traditions are like opera-one needs to have some knowledge and experience in order to get pleasure from them.

Alternatively, nationalism may be looked at as an investment good, as suggested above. It is valuable because it provides connections with people whom an individual may wish to trade, either to get a job, a good plumber, a spouse, etc. In that case, it seems reasonable to assert that the greater the stock of ethnic capital an Italian person (say) has, the larger the productivity of the Italian connection, i.e., the more transaction costs will be reduced when he or she trades with other Italians rather than with other Canadians. Again, this seems entirely plausible.

Now let us proceed to the second property of ethnic nationalism:jointness. Put simply, an individual's ethnicity is positively related to that of other individuals. Looking at ethnicity as a consumption good first, this means, to revert to the Italian example, that it is more fun to sing the Italian national anthem with other Italians than to sing it alone, to read books about the Roman Empire with other Italians than with non-Italians, etc. Alternatively, if ethnicity is looked at as an investment good, jointness implies that investing in ethnicity is more productive when other individuals are doing the same. If, for example, the person in our Italian illustration is Sicilian, it will be more productive to brush up on his Sicilian dialect if other Sicilians are doing the same. Then they can get together and discuss, say, renovating his home in Sicilian dialect ${ }^{11}$. Alternatively, investing in ethnicity may be subject to peer pressure, as suggested in my 1995 paper. In either case, an individual $i$ 's investment or consumption $E$ in period $t$ is positively related to the average level of ethnic consumption, pressure or investment $\bar{E}^{j}$ of other individuals.

Assuming that nationalism has these two properties, it follows that :

"I owe this illustration to conversations with Isidoro Mazza. 
(3)

$$
E_{t}{ }^{i}=f\left(K, \bar{E}^{j-1}\right) \quad f_{k}, f_{E j}>0 . \quad \text { where }
$$

$\bar{E}_{t-1}^{j}=$ average consumption last period by others, $K=\sum^{i} E_{t-1}$ is the accumulated stock, and both first order

partial derivatives are positive.

If this formulation is accepted, then it turns out that nationalism is contagious, possibly highly elastic with respect to changes in prices and incomes which affect producers or consumers in common, and possibly unstable. To see how this works, let us return to the case of Serbia. It seems reasonable to suppose that, in Yugoslavia after Milosevic came to power, the productivity of ethnic networks increased because of the disappearance of the Communist Party, and the replacement in importance of Communist networks by ethnic networks, as widely advertised by Milosevic's "anti-bureaucratic revolution" $1987-9 .{ }^{12}$ The immediate or first period effect (at the beginning of the revolution) of this change on a typical individual's investment or consumption of ethnic nationalism may or may not have been large, but it would have been positive ${ }^{13}$. It follows that each individual will invest in or consume more ethnic capital. Next period, however, every individual will want to invest or consume even more, because: (1) the stock inherited from the last period $K$ is now larger and (2) the average level of investment by others $\left(\bar{E}_{t-1}^{j}\right)$ has also increased. The same thing will happen next period, and so on. So while in the short run , traditional or habit-based and jointly consumed activities may be inelastic with respect to changes that affect their value, in the long run, they tend to be highly

${ }^{12}$ In Russia, they were not so much replaced by ethnic networks as by old connections remaining and strengthening, in the context of a market economy, thus making Russia a "virtual" economy (see Gaddy and Ickes (1998) on this concept) and facilitating links with organized crime.

${ }^{13}$ For the statement in the text to be true, it must technically be assumed that we are looking at an "income-compensated" charge, i.e., a pure substitution effect. 
elastic. There is also a significant possibility of instability, as the interactions based on traditional behaviour and on consumption in common or peer pressure need not dampen out over time but may increase ${ }^{14}$.

So far, ethnic nationalism appears just like other activities which tend to be habitual and jointly engaged in or subject to social pressure, as analysed by Becker ${ }^{15}$. That is, it is like religion (for those who view nationalism positively) or harmful drugs (for those who view it negatively). ${ }^{16}$ There is, however, yet a further interaction that makes the likelihood of instability larger than suggested so far, and differentiates nationalism or ethnic cohesion from these other activities social interactions. This is the interaction of nationalism with the security dilemma.

To illustrate, suppose there is an increase in nationalistic sentiment or cohesion among the Croatians. As we have already seen, this would stimulate fear on the part of the Serbs because of the security dilemma. The increased fear that every Serb would feel then acts just like a change in the price or the marginal productivity of Serbian cohesion, leading each individual to want to raise his level of ethnic involvement. Again, initially, the change may not be very large. Next period, however, this would lead to still greater consumption or investment via the habituation and jointness effects. In turn, this stimulates fears on the part of the Croatians because of the security dilemma, again leading to jointness and habit effects on their part. So the security dilemma and the contagion (habit and jointness) effects interact with each other, possibly accounting for the kind of explosive changes in nationalist sentiment that we have seen in Yugoslavia. ${ }^{17}$

To see these points more precisely, it may be useful to develop a simple diagrammatic apparatus. The

\footnotetext{
${ }^{14}$ There may be, in addition, a synergistic interaction between peer pressure and habituality (Becker, 1996, p. 125).
}

${ }^{15}$ For models of drug addiction see Becker (1996). Iannaccone (1988) models religious behaviour. Other models of social interactions which derive similar implications on the basis of information rather than social interactions include Banerjee (1992), and Hirshleifer, et al. (1998).

${ }^{16}$ The reader who views religion negatively and drugs positively can simply transpose these two in the statement in the text.

${ }^{17}$ A similar analysis would explain the "burst" of patriotism expressed by many countries in wartime. 
phenomenon we are analyzing is dynamic while the diagram is static, but perhaps it will be useful nonetheless. To begin, note first that, from the analysis of nationalism and social interactions, everyone will have his preferred or desired level of ethnic capital $K$, or desired level of investment $E$. The relationship between the two is just

$$
E^{\prime}=\delta K
$$

where $\delta$ is the rate of depreciation of ethnic capital. Assuming that $K$ is the long run level of desired ethnic capital, the satisfaction of (4) simply keeps individual $i$ 's level of ethnic capital at that level. The desired level of ethnic capital, in turn, can be derived from the the equilibrium desired level of ethnic investment. This depends on the external threat, as described previously: to repeat, an increase in, say, Serb ethnic capital stimulates fear on the part of each Croatian (via the security dilemma). This in turn raises the productivity of Croatian ethnic capital $E_{c}$ and stimulates each Croatian to accumulate more (via the contagion effects displayed in equation (3)). But that in turn raises the fear of the Serbs, and stimulates each one to accumulate more Serb ethnic capital (increase his investment $E_{s}$ ). But this in turn raises the fears of the Croats again, and so forth. In other words,

$$
E_{c}=h\left(P_{c}\left(F_{c}\left(E_{s}{ }^{9}\right)\right)\right)
$$

where $E_{c}$ is Croatian ethnic investment in period $\mathrm{t}$ (the time subscripts are omitted for notational simplicity), based on an anticipated Serb investment of $E_{s}^{a} ; F_{c}$ is the level of fear experienced by Croatians from Serb cohesion or ethnic investment, and $P_{c}$ is the productivity of Croatian ethnic capital. A similar relationship exists for Serbian ethnic investment $E_{s}$ :

$$
E_{s}=g\left(P_{s}\left(F_{s}\left(E_{c}^{a}\right)\right)\right)
$$

One possible equilibrium is the Nash equilibrium, where anticipated investments are realized or where:

$$
E_{c}=E_{c}^{a} \text {, and } E_{s}=E_{s}^{a}
$$

This equilibrium is depicted in Figure 1. Serb investment in ethnic capital is on the horizontal axis; Croatian investment is on the vertical one. The curve $C$ defines Croatian ethnic investments $E_{c}$ as a function 
of $E_{s}$; similarly, the curve $S$ defines $E_{s}$ as a function of $E_{c}$. At $X$, all expectations are fulfilled. Inside the zone defined by the two curves and labelled $Z$, each party is, in its own opinion, not secure enough; that is, for any level of Croat ethnic investment, Serbs have not invested enough to make them feel secure, and vice versa. So $Z$ defines the zone of insecurity.

Of course, an equilibrium like $X$ need not exist. A sufficient condition for existence is that all the relationships in (6) and (7) are diminishing or at least non-increasing. In other words, an increase in anticipated Croat ethnic investment $E_{c}{ }^{a}$ ultimately increases the fear of the Serbs $F_{s}$ by the same or by smaller and smaller amounts; similarly, the effect of $F_{s}$ on the productivity of Serb ethnic capital $P_{s}$ and of $P_{s}$ on Serb investment $E_{s}$ is also non-increasing.

Now suppose that an exogenous event occurs such as a rise in the marginal productivity of ethnic capital. The S-curve will shift down towards the horizontal axis as Serbs now want to invest more at any level of Croat ethnic investment. Similarly, the $C$-curve will shift up towards the vertical axis. The two shifts reinforce each other in implying a larger zone of insecurity. If a new equilibrium exists, it necessarily implies larger amounts of both $E_{c}$ and $E_{s}$.

It should be emphasized that, while implied by the model, these processes are not automatic; as always in the case of the security dilemma, the spiral depends, especially for its explosive quality, on a lack of communication between nations or a lack of leadership, either of which may dampen down an explosive reaction. As we know, of course, Milosevic did precisely the opposite and practised the politics of fear. But the analysis also implies that, however malevolent he may have been in setting the fires of nationalism into motion, he did not control them -- the contagion property and security dilemma and their interaction imply that they have the capacity to spread uncontrollably.

From (5), (6) and (7) the most important variables which might give rise to or amplify a spiral are, firstly, the strength of the security dilemma (the elasticity of $F_{s}$ with respect to $E_{c}^{a}$, i.e., the extent to which an increase in Serb ethnic capital stimulates fear on the part of each Croatian, and vice versa), and secondly, 
the marginal productivity of Croatian or Serb ethnic capital. One important factor which affects the magnitude of the security dilemma is the structure of communications, both between the two groups and within them. A "happening" of the Serbs, for example, need not necessarily be interpreted as particularly threatening by other ethnic groups: it could be viewed by non-Serbs as a demonstration of solidarity, as an expression of a desire for security, or as threatening gesture aimed specifically at non Serbs ${ }^{18}$.

The behaviour of the media is one important element in determining which interpretation becomes commonly adopted. For example, contagion can obviously be magnified by the press, via the "politics of outbidding". The industrial organization of the market for media (whether it is a monopoly, competitive or oligopolistic) is relevant here. Snyder \& Ballantyne (1997) argue that oligopoly is actually the market structure most favorable to nationalistic mythmaking and the generation of conflict, processes that tend to amplify contagion. Another situation particularly likely to produce contagion is when a press is newly freed: under these circumstances the press is likely to be oligopolistic and particularly susceptible to outbidding. With respect to Milosevic, it has often been suggested that the press was instrumental in bringing him to power. In particular, it is known that Milosevic chose the tv correspondent who would report to Belgrade from Pristina, the capital of Kosovo, and personally phoned the station almost daily to tell the editors what stories to highlight (Snyder and Ballantine (1997), p. 82). And that "After Milosevic's April 1987 speech in Kosovo, Belgrade TV showed the local Albanian police clubbing the Serbian crowd, and Milosevic saying "“Fromnow on, no one has the right to beat you', but it left out the pictures of the crowd stoning the police" (p. 82). Afterwards, Milosevic used the Kosovo issue as a pretext to purge anti-Milosevic sentiment. But he never achieved an absolute monopoly over the Serb media, although he did control the state tv station and

${ }^{18}$ For example, in Kydd's (1997) model, states may be of several types: "greedy", “security seekers", and they may be "trusting" or "fearful". In the model, security seekers can sometimes take steps to signal their intentions and break out of spirals. 
Belgrade's three major newspapers. ${ }^{19}$ Indeed, he appeared to understand the so-called "vacuum effect"-i.e., the idea that people stop believing propaganda if they are given an unrelieved diet of it, and in fact allowed multiple points of view even on the state controlled media. Of course, to make sure that no viewpoint other than that of the state gained any particular credibility, he made sure that the opposition was diluted, in part by actively subsidising new parties ${ }^{20}$. Consequently, when, after the war, Serbs are observed to complain that there does not seem to be any viable alternative to Milosevic available, that deficiency is not entirely accidental.

The second variable affecting the likelihood of a spiral is the marginal productivity of ethnic capital or nationalism ( the $P_{\mathrm{c}}$ and $P_{s}$ functions in (5) and (6)). These will tend to be affected by such variables as the productivity of alternative means (e.g., the legal system, or the Communist Party) for supporting exchange and by the effectiveness of ethnic enforcement (capacity to prevent, monitor and punish transgressions). One important factor here is the extent to which older traditions have been successfully incorporated into contemporary behaviour by the ethnic group. Thus Hagen (1999) argues that the peculiarity of much behaviour in the Balkans is due to the fact that blood rituals of revenge have been married with modern nationalism, i.e.,to the idea that an individual is responsible for the protection of a wider group than his own family, and in particular for other members of his or her ethnic group. Thus one reason why nationalism did not spread in Slovenia the way it did in Croatia in response to Serbian aggression was simply that there were not many Serbs in Slovenia, hence less fear on the part of the Slovenes that the Serbs would be forced to vanquish them in order to protect their "brothers"21.

\footnotetext{
${ }^{19}$ Ignatieff (1999)argues that understanding the role of the media was a particular gift of Milosevic. See also Ramet (1996), chapter 4, and Mark Thomas (1994)on the media.

${ }^{20}$ Gagnon (1994), p. 124

${ }^{21}$ Another reason, as Janez Sustersic has argued in a personal communication, was that the political agenda was much more open in Slovenia, so that it was impossible for either the communists or the emerging opposition to gain support by nationalism only; they had to advocate and carry out real political and economic reforms as well.
} 
To sum up, I suggest this analysis explains the peculiarly explosive quality of nationalism in Yugoslavia. As Ignatieff (1994) noted, it "spread like wildfire". Or Fearon: "ethnic polarization and conflict in this case has the look of "wildfire" in that the two communities were not nearly so divided only months earlier." (Fearon (1998), p.114). Note that, on the investment model, while the ancient hatreds are not sufficient, they do play a role, since the capital so built may have depreciated but still exists, and new "maintenance" operations such as those performed by Milosevic are capable of restoring it to its previous lustre. Similarly, Serbian aggression and the security dilemma also play an important role. It is doubtful that any of the wars would have occurred without the belligerent leadership of Milosevic, or that his strategies would have been effective without the concerns of the security dilemma. So the security dilemma, Serbian aggression and the existence of ancient hatreds provided the right background or the necessary conditions for the explosion. Ethnic nationalism provided the detonator.

Finally, this analysis sheds some light on the willingness to partake in "ethnic cleansing" which is so difficult to understand. The essential point is that, as we have seen, with social interactions, a person's actions depend on what others are doing and what she herself did in the past. Consequently the morality of those actions to those persons appears similarly contingent. To put it simply, a) once others are doing it, it's a lot easier for another person (you?) to do it; b) it's a lot easier to do it if you have already been doing it in the past $\left.{ }^{22} ; c\right)$ it is a lot easier to do it if you think others are, or are going to be, doing it to you. From this vantage point, it is not so much the operation of hierarchy and the tendency of individuals to obey authority which is responsible for the commission of evil actions, as argued by Hannah Arendt in her celebrated (1976) analysis of the Nazi functionary Eichmann, but the actions of one's comrades and associates and perhaps of one's ancestors. Indeed, I suspect that the emphasis on obedience to authority which was so paramount in

\footnotetext{
${ }^{22}$ The "obedience" experiments of Stanley Milgram (1974) demonstrated the importance of past accommodation to a task, in getting people to do things, such as inflict pain on others, they would otherwise find immoral or distasteful. Akerlof (1991) particularly emphasizes this feature in his model of obedience to authority.
} 
Arendt's line of thought has concealed the importance of peer pressure and contagion in contributing to the willingness to engage in crimes against humanity.

In any case, neither of these considerations (hierarchy ${ }^{23}$ or peer pressure) absolves the individuals involved (eg, the Serbs who actually carried out ethnic cleansing operations) of responsibility for their actions in any way, but it does make their actions, however reprehensible, a lot more understandable ${ }^{24}$. Those who watched and condemned ethnic cleansing from the vantage point of their tv sets were correct to do so, but they would have understood the actions better, and possibly felt more capable of doing them themselves if they recognized the importance of the circumstances of social interactions, habituation and the security dilemma. Perhaps most important, they might not have felt it necessary to condemn an entire people for what happened, as Stacy Sullivan comes close to doing (Sullivan (1999)). Finally, there is a further implication which follows from the contagion properties of ethnic cohesion combined with the security dilemma, if they are understood. Since a small "quantity" of the "virus", i.e., another ethnic group loyalty, can spread quickly and result in many others being "infected" it may be thought that it is necessary to uproot it all.

\section{WHY THE WAR WITH NATO?}

The analysis of this paper also sheds some light on why the war with NATO occurred. The central point is that, in the democracies, belief is widespread that dictators rule by repression alone, and do not need or seek to obtain widespread popular support in order to survive. From this point of view (the existence of this misunderstanding), four propositions can be derived. The first of these is that

\footnotetext{
${ }^{23}$ The problems with Arendt's point of view are discussed in Breton and Wintrobe (1986) and Wintrobe (1998).

${ }^{24} \mathrm{On}$ the mystery presented by these actions, and by the apparent lack of remorse of the Serbian people, even among those who were uninvolved and who opposed the Milosevic regime, see Harden (1999) and especially Sullivan (1999).
} 
1. This misunderstanding on the part of the democracies explains why war occurs so often between dictatorships and democracies and not between democracies.

War is a puzzle for economic theory. The puzzle is that, so long as there are other means of settling a conflict, two powers should never go to war with each other because, as long as they both estimate the outcome correctly, that is, their expectations as to the likely winner are unbiased, wars are irrational. The reason is that there is nothing that can be settled by war that cannot be settled by cheaper, more peaceful means. So, if the likely outcome and its probability are agreed on by both parties in exactly the same way, why not settle in a peaceful manner and save the costs of the conflict? ? $^{25}$

To illustrate, look briefly at the dispute between Milosevic and NATO. While they did not know exactly which side will win, there is no reason to believe that they disagreed on the main points. On the one hand it was obvious that little Serbia was no match for 19 of the most powerful nations in the world, led by the most powerful one, the United States. This led NATO to be certain of the verdict of war. Was not this outcome equally obvious to the Serbs? If so, why did they fight? Serbia, on the other hand, presumably knew that power alone does not win wars. A country has to be led by people with the will to use it. However big a problem this can be for one nation, it is multiplied many times over when 19 nations are involved. Serbia probably knew that while NATO may have been an effective deterrent to nuclear war, in a conventional campaign it was unlikely to be an effective fighting force because of the collective action problem. Its leadership counted on the collective action problem among among the nations of NATO to mean that NATO could not prosecute a war properly.

Of course, NATO knew this as well. So suppose then that the two sides agreed, more or less, on the probable outcome of the conflict. Then why bother to fight in the first place? The war itself merely wastes resources and does not change anything. In brief, so long as the same information on relative strengths is

\footnotetext{
${ }^{25}$ Fearon (1995) is a recent and persuasive discussion of the war puzzle from the rational choice point of view.
} 
available to both sides of the conflict, there is no reason for them to disagree on the probable outcome of the conflict. Therefore they should be able to come to some agreement without engaging in war.

The implication is that there has to be some systematic basis for misunderstanding (or, alternatively, some other difficulty of reaching or enforcing a bargain) for war to occur. In the case of war between democracies and dictatorships, I suggest that one basis for this misunderstanding is the idea, common in democracy, that dictators are typically not supported by their people and rule by repression alone. In this way, the democracies underestimate the capacity of dictatorships to make war. This, in turn, explains why democracies and dictators go to war with each other. Why did war break out between Serbia and NATO? NATO decision-makers wanted Milosevic to sign the Rambouillet accords ${ }^{26}$ and thought that, since Milosevic was not supported by his people, he was in a weak position to resist this type of pressure. By the same token, NATO also failed to understand that for Milosevic to accept the terms of Rambouillet would, by threatening Serbia with the loss of Kosovo, undermine the very basis of his support. ${ }^{27}$ Put crudely, the underlying logic was that all NATO had to do was to drop a few bombs and he would be forced to cave in.

So part of the reason that the war started was because of the assumption in the West that Milosevic had no support and could easily be brought to heel. Once the war began and this turned out not to be the case, the bombing and the logic for escalation acquired a completely different rationale, which was, roughly speaking, that "NATO could not afford to lose to a small-time dictator and maintain its reputation". On this line of thought, the logic of the war completely changed once it began and it began to go badly for the West.

${ }^{26}$ Michael Ignatieff makes the point in his (1999) analysis of the war that the initial bombing campaign was very very light. Note that the declaration by Clinton that he would never use ground troops was also a mistake on the ordinary way of thinking. But our line of thought suggests that these actions were consistent with the rational but mistaken belief that Milosevic, being a dictator, lacked deep political support and therefore was in a weak fighting position.

${ }^{27}$ See Hagen ((1999), p. 59) on this point. 
2. This logic also explains which type of dictatorship democracies will most often go to war with. The order (frequency of expected armed conflict) is predicted to be: totalitarians first, followed by tyrants and then tinpots. The ordering is paradoxical in that it implies that democracies go to war most often with those dictatorships with the most support, i.e, with totalitarian regimes. Note that this is also the case where the argument, often made within the democracies, that by launching sanctions or going to war with dictatorships, the democracies are only causing suffering among innocent people is the weakest. But it is with totalitarian regimes that the misunderstanding on the part of the west is greatest.

\section{This misunderstanding sometimes also makes it hard to wage an effective campaign vs the dictator.}

For example in the Serbian conflict, NATO justified each attack on the grounds that they were only attacking the dictator's power base, which were held to be just the instruments of his repression. The most interesting issue which arose within NATO and was publicly aired was whether it was permissible to attack Serbian tv stations. The idea was that it was only permissible, morally, to attack Milosevic's instruments of repression, and it was implicitly held that the only thing that kept the "dictator" (as Milosevic was usually referred to in the press during the war) in power was repression. The notion that his popular support was his most important power base was never aired during the war, nor the implication that, if it was only permissible to attack his power base, the people of Serbia could be legitimate targets of war ever derived. Accordingly, the idea that dictators rule by repression alone also made it harder for the NATO democracies to wage an effective military campaign against Milosevic. In the same way, it has commonly been asserted that only innocent people were (and are, as of this writing) harmed by the sanctions imposed against Saddam Hussein and Milosevic. 
4. The war enhanced Milosevic's stimulation of Serbian nationalism in many ways, some obvious, some less so. Once the provocation with NATO began, the war helped Milosevic in playing the nationalist game, as has been much discussed but misunderstood. The essential point is simply that war vs the dictator may strengthen the dictator's power, if it expands loyalty to the regime. This can happen in at least four ways:

(1) War accelerates the process in which everyone is put into two groups, "us" and "them", thus forcing even those who dislike the regime to choose between patriotism and treason;

(2) War proves the dictator correct-He has been arguing that you cannot trust the foreign powers-now he is proven right;

(3) War helps to make the dictator indispensable. As Aleksa Djilas put it with respect to the nest-to-last campaign:

"Milosevic counted on war, the ultimate condition of fear, to unite Serbs around him. That is why he refused to look for political solutions to the persecution of Serbs in Croatia after Franjo Tudjman came to power in May 1990, and to the erosion of the Serbs' position in Bosnia-Herzegovina, after the Muslim leader Alija Izetbegovic became its president in November 1990. Milosevic welcomed the Serbs' increased sense of insecurity and was only too glad to pledge them into a war in which they would have only him for protection" (Djilas, 1993, p. 88).

(4) Finally, once the bombing campaign began, fear of NATO replaced the fear of Milosevic. This is another reason why loyalty to the dictator may have increased. To work differently, ie, for the bombing to reduce loyalty to Milosevic the way NATO wanted, it would have been necessary for the Serbs to believe that 'Milosevic is responsible' whenever NATO bombed them. In tum, since Milosevic was supported by many Serbs, this would mean that they would have had to think they were themselves responsible for the bombs falling on their own heads. I suggest that this line of thought was not common among the victims of the bombing campaign. 
For all these reasons, bombing a dictatorship can have the effect of solidifying a dictator's hold on power, as long as it stops short of actually removing him. So it has been argued (eg, by Konrad (1999)) that Milosevic essentially invited NATO's bombing.

At the same time, there was a belief in the West that Milosevic could be useful to the West-"better than anarchy" in the common phrase. In the same way, it is sometimes thought that Saddam Hussein is useful, or the leaders of Communist China. All these dictators are 'better than anarchy.' Consequently it was suggested that the war against Milosevic was not to be too intensive, so that he would remain in power afterwards, in the same way that it was often argued that the goal of bombing in Iraq was not to remove Hussein from power, but to "discipline" him. It is arguable that only the indictment by the UN Tribunal in the Hague closed off this approach to Milosevic. The indictment made it difficult for US and European leaders (and Russian leaders) to be seen negotiating deals with him and to contemplate resurrecting his image in a positive light once he had learned his lesson.

\section{CONCLUSION}

In this paper I have sought to understand the workings of the Milosevic regime and associated phenomena such as the outburst of Serbian nationalism, war, and ethnic cleansing, all from a rational choice point of view. I found that Milosevic's behaviour is comprehensible as the typical response of a ruler faced with a decline in support and the possible collapse of his regime: he used the tools of repression and stimulation of ethnic nationalism in order to survive in power. However, the eruption of ethnic conflict is partly the result of the fact that under certain circumstances nationalism is contagious, and, especially when combined with the security dilemma, can spread uncontrollably. So Milosevic may have initiated events but he did not control them and has himself been burned by the fire of nationalism which he lit in order to shore up his regime.

The leaders of NATO systematically misunderstood the regime. They appeared to believe that 
Milosevic could sign the Rambouillet accords (and therefore was in complete control of his people) and on the other hand that, as a dictator, he ruled by repression and was therefore unsupported by his people, hence easily beaten by NATO. This misunderstanding of the regime partly explains why the war occurred and why initially things went very badly for NATO. Finally, much of what NATO did helped Milosevic in arousing the nationalism of his people and this nationalism appears to be now permanently entrenched in Serbia.

Among the implications of the reasoning in this paper about Western policy towards dictators are the following:

1. Nationalism is volatile, especially in conditions when security is at stake. Therefore one should be very careful about doing things which may help ignite it.

2. The indictment of Milosevic by the Hague appeared to hasten peace.

3. In brief: Don't play with dictators, thinking they can be useful or are a stabilizing force which is better than anarchy. The basic reason why conflict arose with Milosevic was because of the imperfection of democracy there. In the long run, the best policy for the promotion of human rights and the avoidance of ethnic cleansing and war is to strengthen democracy and strengthen the international tribunal for human rights. 


\section{REFERENCES}

Akerlof, George (1991). "Procrastination and Obedience" American Economic Review, 81. 1-19.

Arendt, Hannah, Eichmann in Jerusalem: A Report on the Banality of Evil. Rev. ed., New York: Penguin, 1976.

Banerjee, Abhijit V. (1992). “A Simple Model of Herd Behavior," Quarterly Journal of Economics 107(3), 797-817.

Bates, Robert H. (1983). "Modernization, Ethnic Competition, and the Rationality of Politics in Contemporary Africa", in Donald Rothschild and Viktor A. Olorunsola, State versus Ethnic Claims. Boulder, Colorado: Westview Press.

Becker, Gary S. (1996). Accounting for Tastes (Cambridge: Harvard University Press).

Bernholz, Peter (1997). "Ideology, Sects, State and Totalitarianism: A General Theory", in Maier, Hans and Michael Schaefer, eds., Totalitarismus: und Politische Religionen. Konzepter des Diktaturvergleichs, Vol II. Paderborn, Munchen, Wien, Zurich: Ferdinand Schoeningh, 271-298.

Breton, A., and Ronald Wintrobe (1982), The Logic of Bureaucratic Conduct. New York: Cambridge University Press.

(1986). "The Bureaucracy of Murder Revisited." Journal of Political Economy 94 (1986), 905-926.

Breton, Albert, Gianluigi Galeotti, Pierre Salmon, and Ronald Wintrobe, eds.(1995). Nationalism and Rationality. New York: Cambridge University Press,.

Brown, Michael E. , Owen R. Coté, Jr., Sean M. Lymn-Jones and Steven E. Miller, eds. (1997). Nationalism and Ethnic Conflict (London and Cambridge: MIT Press).

Byman, Daniel, Kenneth Pollock and Gideon Rose (1999). “Can Saddam Be Toppled?”, Foreign Affairs, January/February.

Coleman, James S. (1990), Foundations of Social Theory. Harvard University Press. 
Dallago, Bruno and Milica Uvalic (1998). "The Distrbutive Consequences of Nationalism: The Case of Former Yugoslavia," Europe-Asia Studies 50, 71-90.

Djilas, Aleksa (1993). "A Profile of Slobodan Milosevic," Foreign Affairs, pp. 81-96.

Fearon, James, D. (1995). "Rationalist Explanations for War" International Organization 49, 379-414. (1998). "Commitment Problems and the Spread of Ethnic Conflict", in Lake, David A. and Donald Rothchild (eds.), The International Spread of Ethnic Conflict: Fear, Diffusion, and Escalation (Princeton, NJ: Princeton University Press).

Fearon, James D. and David D. Laitin (1996). "Explaining Inter-Ethnic Cooperation, “ The American Political Science Review 90, 715-735.

Figueiredo, Jr., Ruij P. and Barry R. Weingast (1998). "The Rationality of Fear: Political Opportunism and Ethnic Conflict," Draft, January/June.

Foxley, Alejandro, Michael S. MacPherson and Guillermo O'Donnell (1986). Development, Democracy, and the Art of Trespassing: Essays in Honor of Albert O. Hirschman (Notre Dame: The University of Notre Dame Press).

Friedrich, Karl and Zbigniew Brzezinski (1965). Totalitarian Dictatorship and Autocracy. Cambridge, Mass.: Harvard University Press.

Fukuyama, Francis (1992). The End of History and the Last Man. New York: Free Press.

Gaddy, Clifford, and Barry Ickes (1998). "Beyond the Bailout: Time to face reality about Russia's virtual economy" Foreign Affairs 77: 53-67.

Gagnon, V.P., Jr. (1994). "Serbia's Road to War", in Larry Diamond and Marc F. Plattner, Nationalism, Ethnic Conflict and Democracy. Baltimore and London: Johns Hopkins University Press, .

Gagnon, V.P., Jr, (1994/5). "Ethnic Nationalism and International Conflict: The Case of Serbia" International Security 19, 130-137. Reprinted (1997) in Brown, Michael E., Owen R. Coté, Jr., Sean M. LymnJones and Steven E. Miller, eds. Nationalism and Ethnic Conflict. London and Cambridge: MIT Press. 
Glenny, Misha (1992). The Fall of Yugoslavia. New York: Penguin Books.

Greenfeld, Liah (1992). Nationalism: Five Roads to Modernity (Boston: Harvard University Press).

Hagen, William (1999). “The Balkans' Lethal Nationalisms", Foreign Affairs 78 July/August,52-64

Harden, Blaine (1999). “The Milosevic Generation,"The New York Times Magazine, August 29, 30-61

Hirshleifer, David (1998). "Learning from the Behavior of Others: Conformity, Fads, and Informational Cascades," Journal of Economic Perspectives 12(3), 151-70.

Holbrooke, Richard (1998), To End A War. Revised Edition. New York: Modern Library

Huntington, Samuel (1996). The Clash of Civilizations and the Remaking of World Order. New York: Simon and Schuster.

Iannaccone, Lawrence R (1988). "A Formal Model of Church and Sect", American Journal of Sociology, 94 ( supplement), S241-S268.

Ignatieff, Michael (1994). Blood and Belonging: Journeys into the New Nationalism (Great Britain: Vintage). (1999). “Annals of Diplomacy: Balkan Physics,"The New Yorker, May 10, 68-80.

Katz, Michael, and Carl Shapiro (1985). "Network Externalities, Competition, and Compatibility," American Economic Review, June, 75,424-40.

Konrad (1999). Johnson's Russia List.

Kydd, Andrew (1997). "Game Theory and the Spiral Model”, World Politics 49, 371-400.

Lake, David A. and Donald Rothchild (eds.) (1998). The International Spread of Ethnic Conflict: Fear, Diffusion, and Escalation (Princeton, NJ: Princeton University Press).

Milgram, Stanley (1974). Obedience to Authority: An Experimental View. New York: Harper and Row. Olson, Mancur (1993). "Dictatorship, Democracy and Development," American Political Science Review 87, $567-575$.

Posen, Barry R. (1993). "The Security Dilemma and Ethnic Conflict," Survival 35, 27-47. 
Ramet, Sabrina Petra (1996). Balkan Babel: The Disintegration of Yugoslavia from the Death of Tito to Ethnic War, $2^{\text {od }}$ edition (Boulder, CO: Westview Press).

Smith, Anthony D. (ـ “The Formation of Nationalist Movements", in Anthony D. Smith, Argyle, ed., Nationalist Movements.

(1993). "The Ethnic Sources of Nationalism," Survival 35, 48-62.

Snyder, Jack, and Karen Ballantine (1997). "Nationalism and the Marketplace for Ideas", in Brown, Michael E. , Owen R. Coté, Jr., Sean M. Lymn-Jones and Steven E. Miller, eds. Nationalism and Ethnic Conflict (London and Cambridge: MIT Press).

Sontag, Susan (1999). The Observer,

Sullivan, Stacy (1999). “Milosevic's Willing Executioners," The New Republic, May 10.

Thomas, Mark (1994). "Complete Control," New Statesman and Society 06/24/94 (v7:n308, p.17(1)).

Thomas, Robert (1999). Serbia Under Milosevic: Politics in the 1990s. London: C. Hurst and Co.

Tullock, Gordon, Autocracy. Dordrecht: Martinus Nijihoff, 1987.

Wintrobe, Ronald (1990). "The Tinpot and the Totalitarian: An Economic Analysis of Dictatorship," American Political Science Review 84: 849-872.

(1995). "Some Economics of Ethnic Capital and Conflict," in A. Breton, G. Galeotti, P. Salmon and R. Wintrobe (eds.), Nationalism and Rationality. New York: Cambridge University Press. (1998). The Political Economy of Dictatorship. New York: Cambridge University Press.

Woodward, Susan L. (1995). Balkan Tragedy: Chaos and Disillusion After the Cold War (Washington: The Brookings Institution).

(1997). "Intervention in Civil Wars - Bosnia and Herzegovina," Columbia University Institute of War and Peace Studies, February.

Zimmerman, Warren (1996). Origins of a Catastrophe: Yugoslavia and Its Destroyers. New York: New York Times Books. 


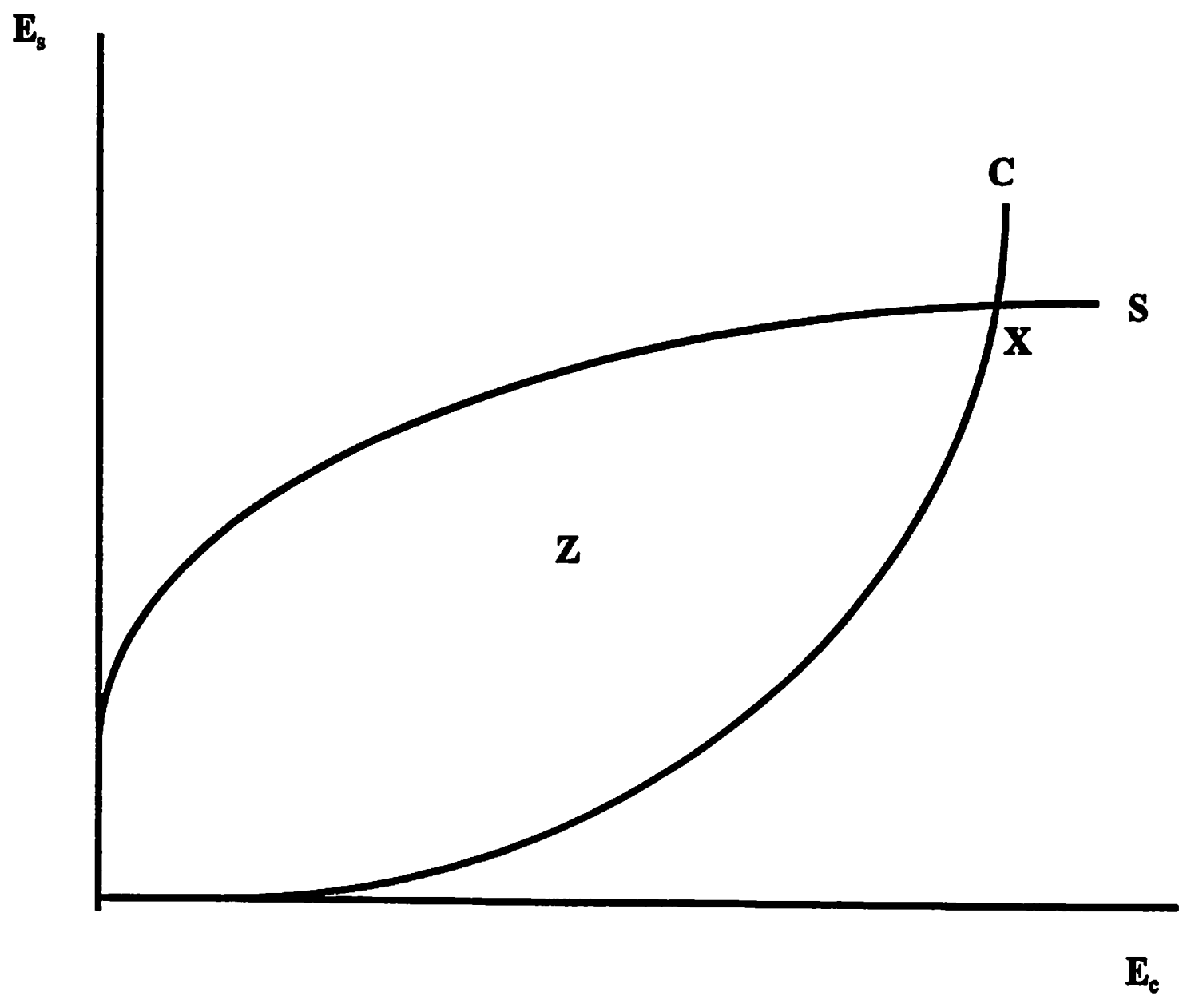

Figure 1 